\section{Interrelationship between periodontics and adult orthodontics}

Ong MA, Wang H-L, Smith FN: Interrelationship between periodontics and adult orthodontics. J Clin Periodontol 1998; 25: 271-277. (C) Munksgaard, 1998.

Abstract. The purpose of this review article is to provide the dental practitioner with an understanding of the interrelationship between periodontics and orthodontics in adults. Specific areas reviewed are how periodontal tissue reacts to orthodontic forces, influence of tooth movement on the periodontium, effect of circumferential supracrestal fiberotomy in preventing orthodontic relapse, effect of orthodontic bands on the periodontium, specific microbiology associated with orthodontic bands, mucogingival considerations and time relationship between orthodontic and periodontal therapy. In addition, the relationship between orthodontics and implant restorations (e.g., using dental implants as orthodontic anchorage) will be discussed.
Marianne A. Ong, Hom-Lay Wang and Frederic N. Smith

Department of Periodontics/Prevention/ Geriatrics, School of Dentistry, University of Michigan, Ann Arbor, MI, USA
Key words: periodontics; orthodontics; tooth
movement; mucogingival defects; microbiology; implants; anchorage

Accepted for publication 12 August 1997
The primary objective of periodontal therapy is to restore and maintain the health and integrity of the attachment apparatus of teeth. In adults, the loss of teeth or periodontal support can result in pathological teeth migration involving either a single tooth or a group of teeth. This may result in the development of a median diastema or general spacing of the teeth with or without incisal proclination, rotation or tipping of bicuspids and molars with the collapse of the posterior occlusion and decreasing vertical dimension. Adjunctive orthodontic therapy is necessary to resolve these problems. Additionally, orthodontic therapy can facilitate management of several restorative and aesthetic problems/difficulties relating to fractured teeth, tipped abutment teeth, excess spacing, inadequate pontic space, malformed teeth, hypererupted incisors and diastema/frena as summarized in Table 1. The purpose of this article is to review issues related to periodontics and adult orthodontics.

\section{Periodontal Tissue Response to Orthodontic Forces}

Tooth movement during orthodontic therapy is the result of placing controlled forces on teeth. Removable appliances place intermittent tipping forces on teeth while fixed appliances can create continuous multidirectional forces to create torquing, intrusive, extrusive, rotational and bodily movement (Lindhe 1989, Proffit 1993a). Age per se is not a contraindication to orthodontic treatment. With increasing age, cellular activity decreases and the tissue becomes richer in collagen (Reitan 1985). In the elderly, the tissue response to orthodontic forces including both cell mobilization and conversion of collagen fibers is much slower than in children and teenagers (Reitan 1985). In adults, hyalinized zones are formed more easily on the pressure side of an orthodontically moved tooth and these

Table 1. Use of orthodontics as an adjunct to overall treatment

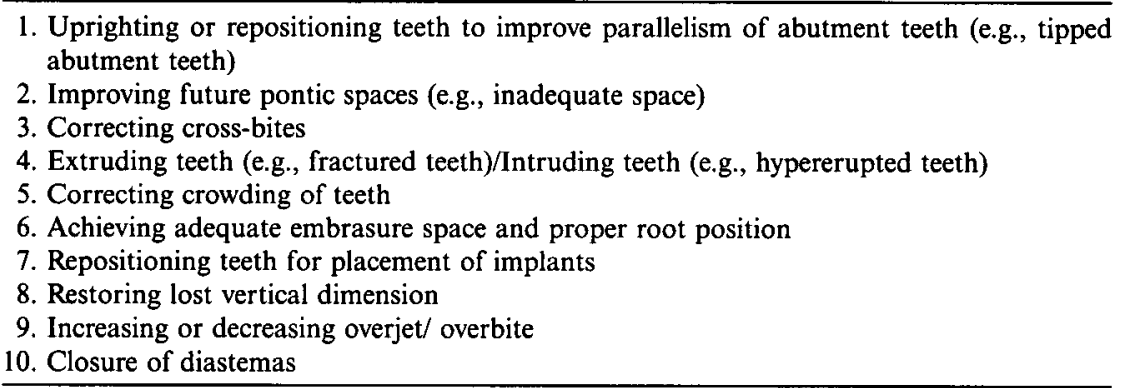


Table 2. Response of the PDL to orthodontic forces

strong forces

( $\gg$ capillary blood pressure)

moderate forces (>capillary blood pressure) light forces

(<capillary blood pressure $\sim 20-25 \mathrm{mmHg}$ )
PDL crushed on pressure side $\rightarrow$ local ischaemia

$\rightarrow$ degeneration of $\mathrm{PDL}=$ hyalinization $\Rightarrow$ delayed tooth movement

strangulation of PDL $\rightarrow$ delay in bone resorption

ischaemia in PDL, tooth movement continuous

with simultaneous bone resorption and formation zones may temporarily prevent the tooth from moving in the intended direction (Reitan 1964). Table 2 summarizes the response of the periodontal ligament (PDL) to various magnitudes of orthodontic forces as described by Gryson (1965).

Bone surrounding a tooth subjected to a force responds in the following manner (Reitan 1985, Proffit 1993a): resorption occurs where there is pressure and new bone forms where there is tension. When pressure is applied to a tooth, there is an initial period of movement for six to eight days as the PDL is compressed. Compression of the PDL results in blood supply being cut off to an area of the PDL and this produces an avascular cell-free zone by a process termed "hyalinization". When hyalinization occurs, the tooth stops moving. This delay in tooth movement varies from short, with the application of light forces, to long periods of time, with heavier forces. The hyalinized zone is eliminated by PDL regeneration that occurs from the reorganization of the area through resorption by the marrow spaces (undermining resorption) and adjacent areas of unaffected PDL and alveolar bone. Once the hyalinized zone is removed, tooth movement can occur again. Regeneration of the PDL does not occur when inflammation is present in the periodontal tissues (Ericsson et al. 1977). Hence, the inflammation needs to be controlled through periodontal treatment.

Unlike in children and adolescents, growth and development have ceased in adults and cannot be influenced by orthodontic movements (Bond 1972, Lindhe 1989). Treatment is thus often limited to different types of tooth alignment. Lindhe (1989) recommends that in the initial stage of orthodontic treatment in adults, an interrupted force of $20-30 \mathrm{~g}$ be used. Later on the force may be increased (up to $30-50 \mathrm{~g}$ in tipping and $50-80 \mathrm{~g}$ in bodily movements, corresponding to a distance of movement of 0.5-1.0 mm. per month) depending on the degree of marginal bone loss and the amount of remaining alveolar bone.
When greater orthodontic forces, such as those needed for prolonged continuous bodily movements and intrusive movements, are employed the chance of development of root resorption is significantly increased (Proffit 1993a). The majority of resorption lacunae are small and generally appear at the border of the PDL hyalinized zone within the marginal and middle thirds of the root. These are soon repaired by apposition of cellular cementum. In contrast, apical root resorption is an irreversible injury and results in permanent shortening of the root (Proffit 1993a). Thus, there is a risk for root resorption in anchorage teeth which are often subjected to heavy loading (Lindhe 1989).

Orthodontic movement of endodontically treated teeth is possible as the response of the PDL and not the pulp is the key element in such movement (Wickwire et al. 1974). Light interrupted forces should be used as there is evidence indicating that such teeth, however, are slightly more prone to root resorption during orthodontics than teeth with normal vitality (Wickwire et al. 1974).

\section{Influence of Tooth Movement on the Periodontium}

When moving teeth orthodontically, the entire periodontal attachment apparatus including the osseous structure, PDL and the soft tissue components moves together with the tooth (Berglundh 1991). Brown (1973) looked at the influence of uprighting molars on the periodontium in four patients. Seven months following the initiation of treatment, the associated pocketing at uprighted molars had $2.5 \mathrm{~mm}$ greater pocket depth reduction than the one control tooth. There was also noted improvement of gingival architecture and less plaque accumulation on the uprighted teeth. In a follow up study on 22 patients with uprighted mandibular molars after an average of 3.5 years, it was reported that pockets on the mesial surfaces were more shallow on the uprighted teeth than on the control teeth
(Kraal et al. 1980). Some case reports have also reported that a reduction of probing depths in intrabony defects following tooth extrusion can be achieved (Ingber 1974, Ingber 1976). In addition, there have been reported cases of localized juvenile periodontitis in which eruption of teeth reduced probing depths (Everett \& Baer 1964, Goldstein \& Fritz 1976). Others have also described the benefits of forced vertical eruption in the exposure of tooth structure to facilitate prosthetic treatment in healthy periodontium $(\mathrm{Gu}$ ilford et al. 1984). The use of extrusive and intrusive forces in healthy periodontium has been studied in animals (Melsen 1986) with favorable results in the presence of oral hygiene. The combination of orthodontic intrusion and periodontal treatment has also been shown to improve reduced periodontal conditions in animals, provided oral hygiene is maintained and tissues are healthy (Melsen et al. 1988). Intrusion of incisors in adult patients with marginal bone loss and deep overbite has been described with root resorption varying from 1 to $3 \mathrm{~mm}$. It is suggested that intrusion is best performed with low forces (5-15 g/tooth) and in the presence of gingival health (Melsen et al. 1989).

Studies have also shown that moving teeth into adjacent osseous defects, orthodontic extrusion with and without fiberotomy and labial tipping of anterior teeth can be successfully accomplished without jeopardizing the periodontal support in the presence of adequate plaque control (Batenhorst \& Bowers 1974, Wingard \& Bowers 1974 , Karring et al. 1982, Polson et al. 1984a, Van Venrooy \& Yukna 1985, Pontoriero et al. 1987, Kozlovsky et al. 1988, Berglundh et al. 1991).

Results extrapolated from animal studies (Ericsson et al. 1977, Ericsson \& Thilander 1978, Ericsson et al. 1978, Ericson \& Thilander 1980) done in dentitions with reduced periodontium show that in the absence of plaque, orthodontic forces and tooth movements do not induce gingivitis. In the presence of 
plaque, however, similar forces can cause angular bone defects and with tipping and intruding movements, attachment loss can occur (Ericsson et al. 1977). In healthy reduced periodontal tissue support regions, orthodontic forces kept within biological limits do not cause gingival inflammation (Ericsson et al. 1977). The most important factor in the initiation, progression and recurrence of periodontal disease in reduced periodontium is the presence of microbial plaque (Ericsson \& Thilander 1978, Ericsson et al. 1978). Clinical studies have demonstrated that with plaque control, teeth with reduced periodontal support can undergo successful tooth movement without compromising their periodontal situation (Eliasson et al. 1982, Boyd et al. 1989).

\section{Effect of Circumferential Supracrestal Fiberotomy (CSF) in Preventing Orthodontic Relapse}

Tooth rotation is simple to achieve but difficult to maintain. Reorganization of collagenous fibers, elastic fibers and the PDL occur after orthodontic tooth movement to accomodate the new tooth positions. In order to achieve proper rearrangement of the supporting tissues of the teeth and to prevent orthodontic relapse, the teeth must be retained for an extended period of time (Proffit 1993b). It is suggested that patients who have had fixed orthodontic appliances to correct intraarch irregularities be on full-time retention for the first 3 to 4 months (Proffit 1993b). Reitan (1959) observed that Sharpey's fibers of the newly formed bundle bone as well as the principal fibers of the PDL (supraalveolar and transseptal fibers) undergo rearrangement even after a retention period of 4 to 6 months. Hence, the retention period should continue on a part-time basis for at least 12 months to allow time for remodelling of these periodontal tissue fibers (Proffit 1993b).

In children and teenagers, it is recommended that the orthodontically moved teeth be "overadjusted" to compensate for future relapse (Lindhe 1989). In adult orthodontics such overcorrections may not be advisable, especially in dentitions with reduced periodontal tissue support (Lindhe 1989).

Edwards (1970) successfully treated 12 post-orthodontically rotated teeth with circumferential supracrestal fiberotomy (CSF). He later published a long-term prospective study of the CSF procedure in alleviating dental relapse following orthodontic treatment (Edwards 1988). A total of 320 consecutively treated control and CSF cases were recorded at approximately 4 and 6 years after active treatment and again at 12 and 14 years after active treatment. The statistical differences between the mean relapses of the control and the CSF cases were highly significant at both time intervals. The CSF procedure reduced the mean relapse by almost $30 \%$. No significant gingival recession on the labial or lingual aspects of the CSF group of teeth was noted.

Reitan (1969) reported that most relapse following orthodontic tooth movement occurred during the first five hours after the appliance was removed. To reduce this relapse caused by the network of elastic supracrestal gingival fibers, CSF surgery should be done toward the end of the finishing phase of active orthodontic treatment, i.e., a few weeks before the removal of the final orthodontic appliance (Proffit 1993c). Such orthodontically treated malaligned teeth would by then have been held in their new positions for several months to allow time for the reorientation of PDL fibers and crestal transseptal fibers (Proffit 1993c).

In addition, Kozlovsky et al. (1988) demonstrated that repeated use of intrasulcular incisions through junctional epithelium and supracrestal connective tissue (i.e., CSF) during forced eruption for clinical crown lengthening of a tooth, can prevent the coronal displacement of the gingiva and attachment apparatus. This can reduce the need for additional recontouring of gingival and osseous tissue after completion of orthodontic movement of the tooth.

\section{Effects of Orthodontic Bands on the Periodontium}

Table 3 summarizes the short- and long-term effects of orthodontic bands on the periodontium. Gingivitis and gingival enlargement appear to be the main short-term effects of orthodontic bands on the periodontium. Baer \& Coccaro (1964) noted that gingival enlargement occurs after placement of a fixed appliance. The condition rapidly improves within 48 hours of the appliance being removed. The increase in probing depth during orthodontic treatment has been attributed by others to this enlargement (Zachrisson \& Zachrisson 1972, Kloehn \& Pfeifer 1974, Alexander 1991). As this gingival enlargement is also seen in patients with good oral hygiene, mechanical irritation caused by the band or cement must be implicated, in addition to trapped plaque (Zachrisson \& Zachrisson 1972, Boyd \& Baumrind 1992). Where such iatrogenic irritations are inevitable, the risk of loss of attachment can be anticipated (Alexander 1991).

Some conflict exists as to the longterm effects of orthodontic bands on the periodontium. Two retrospective studies in adults (Sadowsky \& BeGole 1981, Polson et al. 1988) concluded that no significant damage occurred. In a 2 year post-orthodontic study, Trossello \& Gianelly (1979) compared 30 adult females following multibanded therapy with 30 age-matched control individuals. They found that orthodontically treated patients had a higher prevalence of root resorption $(17 \%$ vs $2 \%$ ) although there was a lower prevalence of mucogingival defects ( $5 \%$ vs $12 \%$ ). This root resorption was most common in the maxillary incisors followed by mandibular incisors. Radiographic crestal bone levels in 104 adult patients, who had completed orthodontic therapy at least 10 years previously, were shown in a cross sectional study to be no different to 76 matched control subjects (Polson \& Reed 1984b). However, Alstad \& Zachrisson (1979) indicated that up to $10 \%$ of 38 children had significant loss of attachment (mean 1-2 $\mathrm{mm}$ ) in 2 years.

In adults, it thus appears that apart from root resorption, orthodontic treatment has minimal detrimental effects on the health of the periodontium in both the short- and long-term.

\section{Table 3. Effects of orthodontic bands on the periodontium}

short-term: gingivitis and gingival hyperplasia not associated with loss of attachment in children (Baer \& Coccaro 1964, Zachrisson \& Zachrisson 1972, Kloehn \& Pfeifer 1974, Alexander 1991)

long-term: no effect in adults (Sadowsky \& BeGole 1981, Polson \& Reed 1984, Polson et al. 1988) some effect - loss of attachment in adolescents (Alstad \& Zachrisson 1979); - root resorption in adults (Trossello \& Gianelly 1979) 
Table 4. Microbiology around orthodontic bands

increase in Lactobacillus (Bloom \& Brown 1964)

increase in motile organisms (Leggott et al. 1984)

increase in anaerobes, Prevotella intermedia and a decrease in facultative anaerobes (Diamanti-Kipioti et al. 1987, Huser et al. 1990)

\section{Specific Microbiology around Orthodontic Bands}

Plaque is a major etiologic factor in the development of gingivitis (Löe et al. 1965). The orthodontic patient's inablility to clean adequately should be expected to contribute to the development of gingival inflammation. In addition a generalized increase in salivary bacterial counts, especially Lactobacillus, has been shown after orthodontic band placement (Bloom \& Brown 1964). Similarly, Leggott et al. (1984) reported 2- to 3- fold increases in both clinical indices and numbers of motile organisms at sites 6 months after appliance placement, and others (Diamanti-Kipioti et al. 1987, Huser et al. 1990) reported early increases in anaerobes and Prevotella intermedia and a decrease in facultative anaerobes. This shift in the subgingival microflora to a periopathogenic population, as summarized in Table 4, is similar to the microflora at periodontally diseased sites (Listgarten \& Hellden 1978).

From studies comparing the microbiological and periodontal responses in adolescents and adults (Leggott et al. 1984, Boyd et al. 1989), it appears that adults are at no greater risk than adolescents of subsequently developing periodontal disease as a result of orthodontic treatment.

\section{Mucogingival Considerations}

The position in which a tooth erupts through the alveolar process and its eventual position in relation to the bucco-lingual dimension of the alveolar process influence the amount of gingiva that will be established around the tooth (Maynard \& Ochsenbein 1975). The initial clinical impression was that a minimum $2 \mathrm{~mm}$ of gingiva, corresponding to $1 \mathrm{~mm}$ of attached gingiva, was necessary for the maintenance of gingival health (Lang \& Löe 1972). Later studies (Miyasato et al. 1977, Dorfman \& Kennedy 1980, Hangorsky \& Bissada 1980, Dorfman \& Kennedy 1982) showed that minimal bands of gingiva can be maintained in periodontal health without progressive recession provided that traumatic toothbrushing and inflammation are controlled.

Trossello \& Gianelly (1979) found in their retrospective study of orthodontically treated adults, a low prevalence of mucogingival defects $(5 \%)$. Other clinical studies (Dorfman 1978, Coatoam et al. 1981) have shown that a narrow band of gingiva is capable of withstanding the stress caused by orthodontic forces. Results from an experimental study (Wennström et al. 1987) indicate that as long as the tooth is moved within the envelope of the alveolar process, the risk of harmful sideeffects on the marginal soft tissue is minimal. Gingival augmentation may be considered when facial tooth movement in the presence of thin keratinized gingiva may result in the establishment of alveolar bone dehiscences with resultant marginal tissue recession (Steiner et al. 1981, Foushee et al. 1985, Maynard 1987, Wennström et al. 1987).

\section{Time Relationship between Orthodontic and Periodontal Therapy}

It is generally recommended that orthodontics be preceded by periodontal therapy based on the belief that orthodontics in the presence of inflammation can lead to rapid and irreversible breakdown of the periodontium (Lindhe et al. 1974). Scaling, root planing (if necessary, by open flap debridement procedures for access) and gingival augmentation should be performed as appropriate before any tooth movement (Glickman 1964, Prichard 1965, Proffit 1993d). The corrective phase of periodontal therapy, i.e., osseous or pocket reduction/ elimination surgery ought to be delayed until the end of orthodontic therapy, because tooth movement may modify gingival and osseous morphology (Goldman \& Cohen 1968).

An adult orthodontic patient may be susceptible to periodontal disease. Therefore close monitoring of marginal periodontal status during the active phase of orthodontic therapy is manda- tory and appropriate supportive periodontal treatment instituted.

\section{Implants and Orthodontics}

The prosthodontic advantages of using implants for orthodontic anchorage were recently recognized (Wehrbein et al. 1993, Wehrbein 1994, Wehrbein et al. 1996). Animal and human investigations have revealed the potential of implants for orthodontic anchorage in preprosthetic tooth alignment (Roberts et al. 1984, Roberts et al. 1989, Higuchi \& Slack 1991, Prosterman et al. 1995). The application of implantorthodontic anchorage has been reported successfully in many clinical situations: retracting and realigning teeth (Odman et al. 1988, Arbuckle et al. 1991, Block \& Hoffman 1995), closing edentulous spaces (Shapiro \& Kokich 1988, Roberts et al. 1989, Roberts et al. 1994), correcting midline and anterior tooth spacing (Odman et al. 1988), reestablishing proper anteroposterior and mediolateral positions for malposed molar abutments (Arbuckle et al. 1991, Haanaes et al. 1991), intruding and/ or extruding teeth (Odman et al. 1988, Haanaes et al. 1991, Salama \& Salama 1993, Southard et al. 1995), correcting a reverse occlusal relationship (Shapiro \& Kokich 1988, Van Roekel 1989, Higuchi \& Slack 1991), correcting an anterior open occlusal relationship (Roberts et al. 1984), protracting one arch or the entire dentition (Higuchi \& Slack 1991) and providing stabilization for teeth with reduced bone support (Odman et al. 1988).

Obtaining proper anchorage for orthodontic tooth movement frequently is a major problem in adult orthodontics due to partial edentulism and reduced amounts of alveolar bone support. Also, in diseased states, severely periodontally involved teeth may experience further periodontal breakdown and may be lost during treatment. In such cases, the option of having such teeth removed and using implants for the needed orthodontic anchorage is becoming a clinical reality, barring the financial costs and extensive multidisciplinary treatment planning that must be done. Implantorthodontic anchorage thus provides a valid treatment option in patients in whom conventional orthodontic treatment may not be indicated because of a periodontally compromised dentition 
that provides inadequate anchorage for the necessary tooth movement.

\begin{abstract}
Summary
Periodontal health is essential for any form of dental treatment. Adult patients must undergo regular oral hygiene instruction and periodontal maintenance in order to maintain healthy gingival tissue during active orthodontic treatment. Close monitoring of adults with reduced periodontal support is mandatory. In conclusion, adult orthodontic tooth movement can be performed on both healthy and diseased periodontia with few detrimental effects (root resorption) provided physiologic forces are used, periodontal inflammation is controlled and meticulous oral hygiene is maintained throughout active therapy. With this basic understanding of periodonticorthodontic interrelationships, the clinician can then work accordingly in the patient's best interest.
\end{abstract}

\section{Acknowledgements}

The authors would like to thank the journal's reviewers for their constructive comments that have been greatly appreciated.

\section{Zusammenfassung}

Wechselbeziehung zwischen Parodontologie und Kieferorthopädie beim Erwachsenen

Dieser Übersichtsartikel soll dem zahnärztlichen Praktiker Verständnis für den wechselseitigen Zusammenhang zwischen der Parodontologie und der Kieferorthopädie beim Erwachsenen vermitteln. Besonders eingehend werden Gebiete besprochen, die sich mit der Reaktion parodontaler Gewebe auf die kieferorthopädischen Kräfte, mit der Auswirkung der Zahnbewegung auf das $\mathrm{Pa}$ rodontium, mit den Folgen der, zur Verhütung von kieferorthopädischem Rezidiv oberhalb der Knochenleiste vorgenommenen, zirkumferenten Faserabtrennung, und der Wirkung kieferorthopädischer Bänder auf das Parodont befassen. Weiterhin wird auf die, mit der Behandlung mit kieferorthopädischen Bändern einhergehende, besondere $\mathrm{Mi}$ krobiologie hingewiesen. Außerdem werden Überlegungen über die Rolle der Mukogingiva und die zeitliche Beziehung zwischen kieferorthopädischer und Parodontalbehandlung angestellt. Darüber hinaus wird die Wechselwirkung zwischen Kieferorthopädie und implantatgetragenem Zahnersatz (wie z.B. bei Anwendung von Implantaten zu kieferorthopädischer Verankerung) diskutiert.

\section{Résumé}

Parodontologie et orthodontie chez l'adulte Le but de cette revue a été d'apporter aux praticiens une explication de la relation existant entre la parodontologie et l'orthodontie chez l'adulte. Les sujets analysés sont: comment le tissu parodontal réagit-il aux forces orthodontiques? Quelle est l'influence du mouvement dentaire sur le parodonte? Quel est l'effet de la fibrotomie supracrestale circulaire dans la prévention de la rechute orthodontique? Quels sont les effets exercés par les bandes orthodontiques sur le parodonte? $Y$ a-t-il une flore spécifique associée aux bandes orthodontiques? Quelles sont les considérations mucogingivales? Quelle est la relation temps entre l'orthodontie et le traitement parodontal? De plus la relation entre l'orthodontie et la restauration par implant (c.-à-d. l'utilisation d'implants dentaires en tant qu'ancrages orthodontiques) est également discutée.

\section{References}

Alexander, S. A. (1991) Effects of orthodontic attachments on the gingival health of permanent second molars. American Journal of Orthodontics \& Dentofacial Orthopedics 100, 337-340.

Alstad, S. \& Zachrisson, B. U. (1979) Longitudinal study of periodontal conditions associated with orthodontic treatment in adolescents. American Journal of Orthodontics 76, 277-286.

Arbuckle, G. R., Nelson, C. L. \& Roberts, W. E. (1991) Osseointegrated implants and orthodontics. Oral Maxillofacial Surgery Clinics of North America 3, 903-919.

Baer, P. N. \& Coccaro, P. J. (1964) Gingival enlargement coincident with orthodontic therapy. Journal of Periodontology 35, 436-439.

Batenhorst, K. F. \& Bowers, G. M. \& Williams, J. E. Jr (1974) Tissue changes resulting from facial tipping and extrusion in monkeys. Journal of Periodontology 45, 660-668.

Berglundh, T., Marinello, C., Lindhe, J., Thilander, B. \& Liljenberg, B. (1991) Periodontal tissue reactions to orthodontic extrusion, an experimental study in the dog. Journal of Clinical Periodontology 18, 330336.

Block, M. S. \& Hoffman, D. R. (1995) A new device for absolute anchorage for orthodontics. American Journal of Orthodontics \& Dentofacial Orthopedics 107, 251258.

Bloom, R. H. \& Brown, L. R. (1964) A study of the effects of orthodontic appliances on oral microbial flora. Oral Surgery Oral Medicine Oral Pathology 17, 658-667.

Bond, J. A. (1972) The child versus the adult. Dental Clinics of North America 16, 401412.

Boyd, R. L., Leggott, P. J, Quinn, R. S., Eakle, W. S. \& Chambers, D. W. (1989) Periodontal implications of orthodontic treat- ment in adults with reduced or normal periodontal tissues versus those of adolescents. American Journal of Orthodontics \& Dentofacial Orthopedics 96, 191-198.

Boyd, R. L. \& Baumrind, S. (1992) Periodontal considerations in the use of bands or bonds on molars in adolescents and adults. Angle Orthodontist 62, 117-126.

Brown, S. (1973) The effect of orthodontic therapy on certain types of periodontal defects (I). Clinical findings. Journal of Periodontology 44, 742-756.

Coatoam, G. W., Behrents, R. G. \& Bissada, N. F. (1981) The width of keratinized gingiva during orthodontic treatment. Its significance and impact on periodontal status. Journal of Periodontology 52, 307-313.

Diamanti-Kipioti, A., Gusberti, F. A. \& Lang, N. P. (1987) Clinical and microbiological effects of fixed orthodontic appliances. Journal of Clinical Periodontology 14, 326-333.

Dorfman, H. S. (1978) Mucogingival changes resulting from mandibular incisor tooth movement. American Journal of Orthodontics 74, 286-297.

Dorfman, H. S., Kennedy, J. E. \& Bird, W. C. (1980) Longitudinal evaluation of free autogenous gingival grafts. Journal of Clinical Periodontology 7, 316-324.

Dorfman, H. S., Kennedy, J. E. \& Bird, W. C. (1982) Longitudinal evaluation of free gingival grafts. A four-year report. Journal of Periodontology 53, 349-352.

Edwards, J. G. (1970) A surgical procedure to eliminate rotational relapse. American Journal of Orthodontics 57, 35-46.

Edwards, J. G. (1988) A long term prospective evaluation of circumferential supracrestal fiberotomy in alleviating rotational relapse. American Journal of Orthodontics \& Dentofacial Orthopedics 93, 380-387.

Eliasson, L., Hugoson, A., Kurol, J. \& Siwe, H. (1982) The effects of orthodontic treatment on periodontal tissues in patients with reduced periodontal support. European Journal of Orthodontics 4, 1-9.

Ericsson, I., Thilander, B., Lindhe, J. \& Okamoto, H. (1977) The effect of orthodontic tilting movements on the periodontal tissues of infected and non-infected dentitions in dogs. Journal of Clinical Periodontology 4, 278-293.

Ericsson, I. \& Thilander, B. (1978) Orthodontic forces and recurrence of periodontal disease. American Journal of Orthodontics 74, 41-50.

Ericsson, I., Thilander, B. \& Lindhe, J. (1978) Periodontal conditions after orthodontic tooth movement in the dog. Angle Orthodontist 48, 210-218.

Everett, F. G. \& Baer, P. N. (1964) A preliminary report on the treatment of the osseous defect in periodontosis. Journal of Periodontology 35, 429-435.

Foushee, D. G., Moriarty, J. D. \& Simpson, D. M. (1985) Effects of mandibular orthognathic treatment on mucogingival tissue. Journal of Periodontology 56, 727-733.

Glickman, I. (1964) Clinical periodontology, 
3rd edition, pp. 820-833. Philadelphia: Saunders.

Goldman, H. \& Cohen, D. W. (1968) Periodontal therapy, 4th edition, p 518-567. St Louis: CV Mosby.

Goldstein, M. C. \& Fritz, M. E. (1976) Treatment of periodontosis by combined orthodontic and periodontal approach: report of a case. Journal of the American Dental Association 93, 985-990.

Gryson, J. (1965) Changes in the periodontal ligament incident to orthodontic therapy. Journal of Western Society Periodontol Abstracts 13, 14-21.

Guilford, H. J., Grubb, T. A. \& Pene, D. L. (1984) Vertical extrusion: a standardized technique. Compendium of Continuing Education in Dentistry 5, 562-567.

Haanaes, H. R., Stenvik, A., Beyer-Olsen, E. S., Tryti, T. \& Faehn, O. (1991) The efficacy of two-stage titanium implants as orthodontic anchorage in the preprosthodontic correction of third molars in adultsa report of three cases. European Journal of Orthodontics 13, 287-292.

Hangorsky, U. \& Bissada, N. F. (1980) Clinical assessment of free gingival graft effectiveness on the maintenance of periodontal health. Journal of Periodontology 51, 274 278.

Higuchi, K. W. \& Slack, J. M. (1991) The use of titanium fixtures for intraoral anchorage to facilitate orthodontic tooth movement. International Journal of Oral Maxillofacial Implants 6, 338-344.

Huser, M. C., Baehni, P. C. \& Lang, R. (1990) Effects of orthodontic bands on microbiologic and clinical parameters. American Journal of Orthodontics \& Dentofacial Orthopedics 97, 213-218.

Ingber, J. S. (1974) Forced eruption. Part I. A method of treating isolated one and two wall infrabony osseous defects - rationale and case report. Journal of Periodontology 45, 199-206.

Ingber, J. S. (1976) Forced eruption (II). A method of treating nonrestorable teeth Periodontal and restorative considerations. Journal of Periodontology 47, 203216.

Karring, T., Nyman, S., Thilander, B. \& Magnusson, I. (1982) Bone regeneration in orthodontically-produced alveolar bone dehiscences. Journal of Periodontal Research 17, 309-315.

Kloehn, J. S. \& Pfeifer, J. S. (1974) The effect of orthodontic treatment on the periodontium. Angle Orthodontist 44, 127-134.

Kozlovsky, A., Tal, H. \& Lieberman, M. (1988) Forced eruption combined with gingival fiberotomy: a technique for clinical crown lengthening. Journal of Clinical Periodontology 15, 534-538.

Kraal, J. H., Digiancinto, J. J., Dail, R. A., Lemmerman, K \& Peden, J. W. (1980) Periodontal conditions in patients after molar uprighting. Journal of Prosthetic Dentistry 43, 156-162.

Lang, N. P. \& Löe, H. (1972) The relationship between the width of keratinized gin- giva and gingival health. Journal of Periodontology 43, 623-627.

Leggott, P. J., Boyd, R. L., Quinn, R. S., Eakle, W. S. \& Chambers, D. W. (1984) Gingival disease patterns during fixed orthodontic therapy: Adolescents versus adults. Journal of Dental Research 63 (special issue), 309 (abstr. 1245).

Lindhe, J. \& Svanberg, G. (1974) Influence of trauma from occlusion on progression of experimental periodontitis in the beagle dog. Journal of Clinical Periodontology 1 , 3-14.

Lindhe, J. (1989) Textbook of clinical periodontology, 2nd edition, pp. 563-589. Copenhagen: Munksgaard.

Listgarten, M. A. \& Hellden, L. (1978) Relative distribution of bacteria at clinically healthy and periodontally-diseased sites in humans. Journal of Clinical Periodonto$\log y 5,115-132$.

Löe, H., Theilade, E. \& Jensen, S. B. (1965) Experimental gingivitis in man. Journal of Periodontology 36, 177-187.

Maynard, J. G. Jr. \& Ochsenbein, C. (1975) Mucogingival problems, prevalence and therapy in children. Journal of Periodonto$\log y$ 46, 543-552.

Maynard, J. G. (1987) The rationale for mucogingival therapy in the child and adolescent. International Journal of Periodontics \& Restorative Dentistry 7, 36-51.

Melsen, B. (1986) Tissue reaction following application of extrusive and intrusive forces to teeth in adult monkeys. American Journal of Orthodontics 6, 469-475.

Melsen, B., Agerbaek, N., Eriksen, J. \& Terp, S. (1988) New attachment through periodontal treatment and orthodontic intrusion. American Journal of Orthodontics \& Dentofacial Orthopedics 2, 104 116.

Melsen, B., Agerbaek, N., Markenstam, G. (1989) Intrusion of incisors in adult patients with marginal bone loss. American Journal of Orthodontics \& Dentofacial Orthopedics 3, 232-241.

Miyasato, M., Crigger, M. \& Egelberg, J. (1977) Gingival conditions in areas of minimal and appreciable width of keratinized gingiva. Journal of Clinical Periodontology 4, 200-209.

Odman, J., Lekholm, U., Jemt, T., Branemark, P. I. \& Thilander, B. (1988) Osseointegrated titanium implants: a new approach in orthodontic treatment. European Journal of Orthodontics 10, 98-105.

Polson, A. M., Caton, J., Polson, A., Nyman, S., Novak, J. \& Reed, B. (1984a) Periodontal response after tooth movement into intrabony defects. Journal of Periodontology 55, 197-202.

Polson, A. M. \& Reed, B. E. (1984b) Long term effect of orthodontic treatment on crestal alveolar bone levels. Journal of Periodontology 55, 28-34.

Polson, A. M., Subtelny, J. D., Meither, S. W., Polson, A. P., Sommers, E. W., Iker, H. P. \& Reed, B. E. (1988) Long-term periodontal status after orthodontic treat- ment. American Journal of Orthodontics \& Dentofacial Orthopedics 93, 51-58.

Pontoriero, R., Celenza, F., Ricci, G. \& Carnevale, G. (1987) Rapid extrusion with fiber resection: a combined orthodonticperiodontic treatment modality. International Journal of Periodontics \& Restorative Dentistry 7, 31-43.

Prichard, J. F. (1965) Advanced periodontal disease: surgical and prosthetic management, 1st edition, p. 457. Philadelphia: Saunders.

Proffit, W. R. \& Fields, H. W. (1993a) Contemporary orthodontics, 2nd edition, pp. 266-288. St Louis: CV Mosby.

Proffit, W. R. \& Fields, H. W. (1993b) Contemporary orthodontics, 2nd edition, pp. 534-551. St Louis: CV Mosby.

Proffit, W. R. \& Fields, H. W. (1993c) Contemporary orthodontics, 2nd edition, pp. 530-533. St Louis: CV Mosby.

Proffit, W. R. \& Fields, H. W. (1993d) Contemporary orthodontics, 2nd edition, pp. 558. St Louis: CV Mosby.

Prosterman, B., Prosterman, L., Fisher, R. \& Gornitsky, M. (1995) The use of implants for orthodontic correction of an open bite. American Journal of Orthodontics \& Dentofacial Orthopedics 107, 245-250.

Reitan, K. (1959) Tissue rearrangement during retention of orthodontically rotated teeth. Angle Orthodontist 29, 105-113.

Reitan, K. (1964) Effects of force, magnitude and direction of tooth movement on different alveolar bone types. Angle Orthodontist 34, 244-255.

Reitan, K. (1969) Principles of retention and avoidance of post-treatment relapse. American Journal of Orthodontics 55, 776790.

Reitan, K. (1985) Biomechanical principles and reactions. In Current orthodontic concepts and techniques, eds. Graber, T.M. \& Swain, B.F., pp. 101-192. St Louis: CV Mosby.

Roberts, W. E., Smith, R. K., Zilberman, Y., Mozsary, P. G. \& Smith, R. S. (1984) Osseous adaptation to continuous loading of rigid endosseous implants. American Journal of Orthodontics 86, 95-111.

Roberts, W. E., Helm, F. R., Marshall, K. J. \& Gongloff, R. K. (1989) Rigid endosseous implants for orthodontic and orthopedic anchorage. Angle Orthodontist 59, 247-256.

Roberts, W. E., Marshall, K. J. \& Mozsary, P. G. (1990) Rigid endosseous implant utilized as anchorage to protract molars and close an atrophic extraction site. Angle Orthodontist 60, 135-152.

Roberts, W. E., Nelson, C. L. \& Goodacre, C. J. (1994) Rigid implant anchorage to close a mandibular first molar extraction site. Journal of Clinical Orthodontics 28, 693-704.

Sadowsky, C. \& BeGole, E. A. (1981) Long term effects of orthodontic treatment on periodontal health. American Journal of Orthodontics 80, 156-172.

Salama, H. \& Salama, M. (1993) The role 
of orthodontic extrusive remodeling in the enhancement of soft and hard tissue profiles prior to implant placement: a systematic approach to the management of extraction site defects. International Journal of Periodontics \& Restorative Dentistry 4, 312-333.

Shapiro, P. A. \& Kokich, V. G. (1988) Uses of implants in orthodontics. Dental Clinics of North America 32, 539-550.

Southard, T. E., Buckley, M. J., Spivey, J. D., Krizen, K. E. \& Casko, J. S. (1995) Intrusion anchorage potential of teeth versus rigid endosseous implants: a clinical and radiographic evaluation. American Journal of Orthodontics \& Dentofacial Orthopedics 107, 115-120.

Steiner, G. G., Pearson, J. K. \& Ainamo, J. (1981) Changes of the marginal periodontium as a result of labial tooth movement in monkeys. Journal of Periodontology 52, 314-320.

Trossello, V. K. \& Gianelly, A. A. (1979) Orthodontic treatment and periodontal status. Journal of Periodontology 50, 665-671.

Van Roekel, N. B. (1989) Use of Branemark system implants for orthodontic anchorage: report of a case. International Journal of Oral Maxillofacial Implants 4, 341-344.

Van Venrooy, J. \& Yukna, R. (1985) Orthodontic extrusion of single-rooted teeth affected with advanced periodontal disease. American Journal of Orthodontics 87, 67-74.

Wehrbein, H. \& Diedrich, P. (1993) Endosseous titanium implants during and after orthodontic load - an experimental study in the dog. Clinical Oral Implants Research 2, $76-82$.

Wehrbein, H. (1994) Endosseous titanium implants as orthodontic anchoring elements. Experimental studies and clinical application. Fortschr Kieferorthop 5, 236-250.

Wehrbein, H., Merz, B.R., Diedrich, P. \& Glatzmaier, J. (1996) The use of palatal implants for orthodontic anchorage. Design and clinical application of the orthosystem. Clinical Oral Implants Research 4, 410-416.

Wennström, J. L., Lindhe, J., Sinclair, F. \& Thilander, B. (1987) Some periodontal tissue reactions to orthodontic tooth movement in monkeys. Journal of Clinical Periodontology 14, 121-129.

Wickwire, N. A., McNeil, M. H., Norton, L. A., Duell, R. C. (1974) The effects of tooth movement upon endodontically treated teeth. Angle Orthodontist 44, 235-242.

Wingard, B. S. \& Bowers, G. M. (1976) The effects on facial bone from facial tipping of incisors in monkeys. Journal of Periodontology 47, 450-454.

Zachrisson, S. \& Zachrisson, B. U. (1972) Gingival condition associated with orthodontic treatment. Angle Orthodontist 42, 26-34.

Address:

Hom-Lay Wang

University of Michigan

School of Dentistry

1011 N. University Ave.

Ann Arbor, Michigan 48109-1078

$U S A$

Fax: +1 3137635503

e-mail: homlay@umich.edu 
This document is a scanned copy of a printed document. No warranty is given about the accuracy of the copy. Users should refer to the original published version of the material. 